\title{
OCCURRENCE AND DISTRIBUTION OF FISH IN RIVERS OF LATVIA
}

\author{
Jānis Birzaks, Ēriks Aleksejevs and Māris Strūğis \\ Fish Resources Research Department, Institute of Food Safety, Animal Health and Environment, "BIOR" \\ Daugavgrivvas iela 8, Rīga, LV-1048, LATVIA \\ E-mail: janis.birzaks@bior.gov.lv, eriks.aleksejevs@bior.gov.lv, maris.strugis@bior.gov.lv
}

Communicated by Viesturs Melecis

\begin{abstract}
This publication is a review of data on fish and lamprey species found in 435 of Latvia's rivers and related reservoirs. A total of 43 fish species and three lamprey species, whose life cycles are, at least in part, associated with rivers, have been recorded. These can be divided into freshwater species and diadromous species. Differences between chronologically older publications and records collected since 1990 on fish occurrence are examined. Since 1990, the intensity of study of Latvia's rivers has increased, which is the reason for changes in the conception of the distribution and occurrence of fish species. The authors propose a new fish species list for Latvia's rivers, based on the newest field research and fishery data. The species included in list were caught in research trips during the period 1990 - 2010, or their capture was confirmed by an expert.
\end{abstract}

Key words: river fish, distribution and occurrence of fish species, Latvia.

\section{INTRODUCTION}

Reviews on fish species occurring in Latvia, including rivers, have been previously published, with more thorough accounts during the past 75 years (Grosse, 1935; Mansfelds, 1936; Siliñ̌š, 1936; Priedītis, 1947; Николаев, 1953; Sloka, 1956; 1966; 1974; Eipurs, 1984; Plikšs un Aleksejevs, 1998). However, they have mostly been published in Latvian, and have thus been unavailable to a wider audience.

According to several sources in the literature, Latvia's rivers contain approximately 57 species of fish and three lamprey species. However, many of these records have not been scientifically validated, nor have they been verified in later studies.

Since 1990, the authors have personally organized and taken part in field research on fish resources in Latvia's rivers and reservoirs. During that time, data has been collected on fish occurrence and relative population size in more than 300 of Latvia's rivers and associated reservoirs.

The aim of the study was to summarise the records on fish available in the literature and in recent studies on fish species occurrence and distribution in rivers of Latvia. We sought to answer the following questions 1) what are the reasons for differences between fish species lists proposed by different authors; 2) do older data comply with that obtained after 1990 in rivers of Latvia; 3) what are the newest opinions in fish nomenclature regarding species recorded in rivers of Latvia?

\section{CHARACTERISTICS OF RIVERS IN LATVIA}

There are about 12300 rivers in Latvia with a total length of $38000 \mathrm{~km}$. Only 768 rivers are longer than $10 \mathrm{~km}$ and 17 are longer than $100 \mathrm{~km}$ (Pastors, 1988). The density of rivers in Latvia is $0.59 \mathrm{~km} / \mathrm{km}^{2}$. In accordance with Directive 2000/60/EC, rivers in Latvia are included in the European Ecoregion No. 15 - Baltic Province. This region encompasses the rivers of the eastern part of the Baltic Sea basin - the rivers enter the Baltic Sea in its central part, in the Gulf of Riga and through the river Narva into the Gulf of Finland.

There are multiple sources of water supply to Latvian rivers, the yield of which has been estimated in the following relative proportions: $45-55 \%$ snow melt, $20-30 \%$ rainwater. Latvia's rivers overflow in spring, and in winter and summer water levels usually are low. The low water period in the rivers is not stable, and short-term floods are common in summer after rain or during winter snow smelt.

In the ice-less period, the water temperature in rivers is about $1-2{ }^{\circ} \mathrm{C}$ lower than the air temperature. In summer, the water is cooler $\left(\mathrm{T}<17^{\circ} \mathrm{C}\right)$ in brooks and small and medium size rivers supplied from groundwater and springs. In winter the water temperature in rivers is about $0{ }^{\circ} \mathrm{C}$.

The waters of Latvia's rivers are classified as a hydrocarbon type with a low $(<200 \mathrm{mg} / \mathrm{l})$ or medium $(200-500 \mathrm{mg} / \mathrm{l})$ level of mineralization. Rivers in the Lielupe basin are highly mineralized, reaching, for example, a level up to $1000-1300 \mathrm{mg} / \mathrm{l}$ in the river Mūsa (Anonymous, 1984). 
Many of Latvia's rivers have been transformed, dredged and/or straightened. At least 700 anthropogenic obstacles creating reservoirs have been constructed in the rivers; their number and total area is not available in statistical registers. According to Latvia's River Basin Districts management plans, the ecological quality of the rivers was assessed as inadequate in $1 / 3$ of the largest or medium size streams, according to Directive (2000/60/EC) requirements (Anonymous, 2009).

\section{DATA SOURCES}

This study uses data from many sources. This information has not been previously summarized and compared with new inventory. The article contains data from the first available publications on fish found in Latvia until today. The oldest publications are descriptions of the fauna of the Eastern Baltic region; specific studies of Latvia's rivers were begun only in the 1950's. The archives of the now-defunct Baltic Fish Conservation and Reproduction Administration was an important data source for the time period of 1949-1990. During that time, fishery companies were required to provide regular (monthly) reports of catches. Information on fish stocking was collected from official reports and archives.

Up until 1990, the scientific literature and official reports include records of 280 rivers that contained at least one species of fish. In most cases, only the target species of anglers and commercial fisheries were recorded.

Wider-scope studies on the fish in Latvia's rivers were conducted by the Latvian Fisheries Research Institute starting in 1990. Since then, fish sampling has been conducted within various projects at a total of 1065 time and in 313 rivers. Electrofishing was used in 209 rivers; seines or drag nets in the remaining rivers. Also 32 reservoirs, where fish were caught either with gill nets or seines, were surveyed. Locations of the fish sampling sites are shown in Figure 1 using a $5 \times 5 \mathrm{~km}$ grid.
In preparing this publication, data from various sources was collected, encompassing a total of 435 rivers and 209 associated reservoirs, in which at least one species of fish was recorded. Since 1990, 39 fish species with 138495 individuals have been recorded in rivers and 25 species with 10271 individuals in reservoirs. Capture of some rare species has been reported by commercial fishermen.

The scientific names used in this article are in accordance with the Handbook of European Freshwater Fishes (Kottelat and Freyhof, 2007). In cases when it was impossible to determine the correct species under the recent classification, the species is listed as "spp".

\section{FORMER STUDIES}

The first publications on fish species found in the Eastern Baltic region are from the $18^{\text {th }}$ and $19^{\text {th }}$ centuries. In early studies of the region's fauna, species were reported using their scientific names, as well as their common names in Latvian; some rivers are also mentioned (Fischer, 1791; Schweder, 1893). Kawall (1858) recorded most of the fish species found in Latvia's rivers today, indicating their locations, which were sampled mostly in the western part of Latvia in Kurzeme (Kurland). It must be noted that it was not always possible to determine, according to current nomenclature, which species was recorded. In a study on Cyprinidae species found in rivers, the Daugava River was discussed separately (Dybowski, 1862).

The oldest source on the fish fauna of rivers in Latvia is a popular-science article on the Daugava River and its economic importance, which was written at the end of the $19^{\text {th }}$ century. In the preface of the book, it is mentioned that the fish data were obtained from the authors personal correspondence with voluntary reporters (Сапунов, 1893). A later-published work on fish distribution in the Eastern Baltic is considered to be as the first notable description of the area's fish (Schneider, 1925).

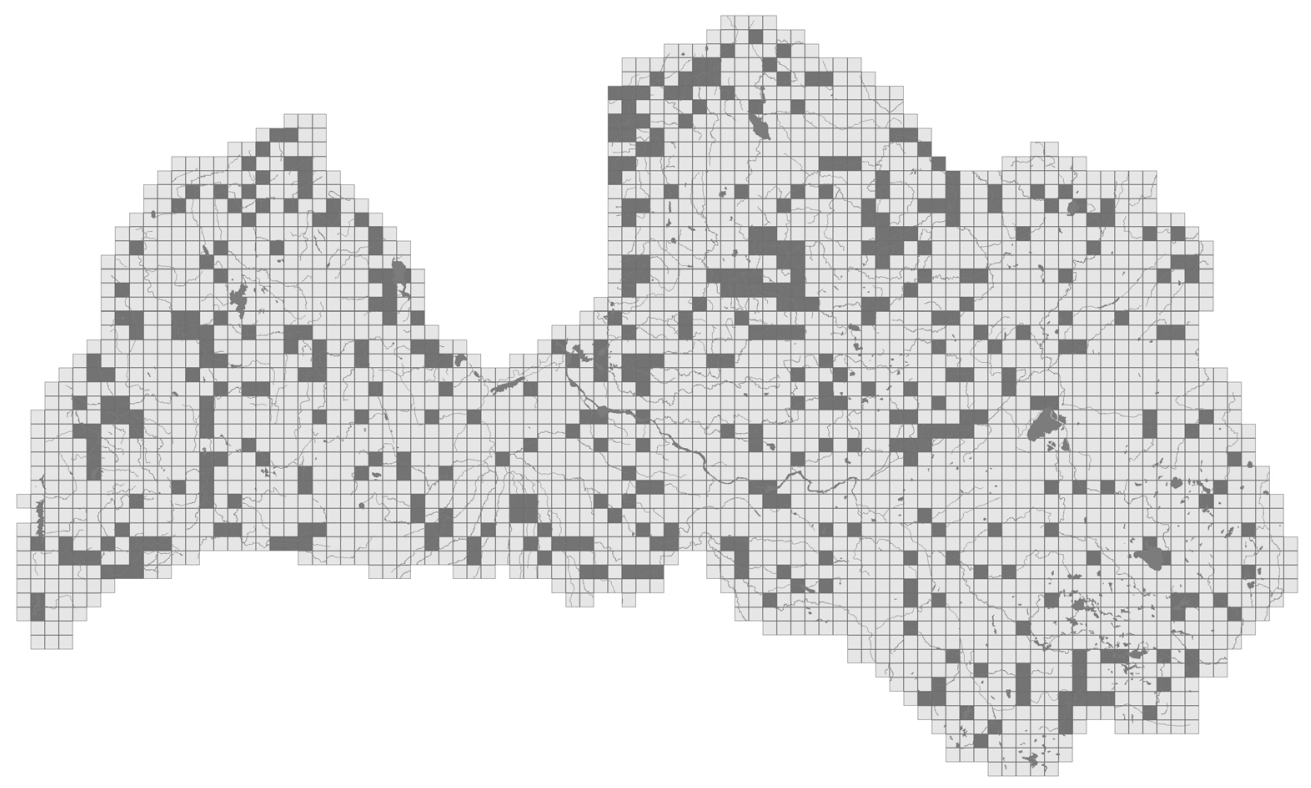

Fig. 1. Fish sampling in rivers of Latvia. Marked squares are $5 \times 5 \mathrm{~km}$ areas containing at least one sampling site. 
The first ichthyofauna lists in Latvia were published in the 1930s. In these publications freshwater and saltwater species were grouped together. Usually, the data sources were not mentioned, excepting a few references to previous publications (Grosse, 1935; Mansfelds, 1936; Siliňš, 1936). The following fish and lamprey species have been recorded in rivers of Latvia: river lamprey Lampetra fluviatilis, brook lamprey Lampetra planeri, sea lamprey Petromyzon marinus, Atlantic sturgeon Acipenser sturio, eel Anguilla anguilla, allis shad Alosa alosa, twaite shad Alosa fallax, bitterling Rhodeus amarus, gudgeon Gobio gobio, crucian carp Carassius carassius, carp Cyprinus carpio, bream Abramis brama, schneider Alburnoides bipunctatus, bleak Alburnus alburnus, asp Aspius aspius, blue bream Ballerus ballerus, silver bream Blicca bjoerkna, sun bleak Leucaspius delineatus, ide Leuciscus idus, dace Leuciscus leuciscus, ziege Pelecus cultratus, minnow Phoxinus phoxinus, roach Rutilus rutilus, rudd Scardinius erythropthalmus, chub Squalius cephalus, vimba Vimba vimba, tench Tinca tinca, spined loach Cobitis taenia, weather loach Misgurnus fossilis, stone loach Barbatula barbatula, catfish Silurus glanis, pike Esox lucius, smelt Osmerus eperlanus, whitefish Coregonus lavaretus, Atlantic salmon Salmo salar, trout Salmo trutta in two forms (migratory and sedentary), grayling Thymallus thymallus, burbot Lota lota, threespine stickleback Gasterosteus aculeatus, ninespine stickleback Pungitius pungitius, bullhead Cottus gobio, ruffe Gymnocephalus cernua, perch Perca fluviatilis, and pike perch Sander lucioperca.

Authors of the various publications have provided their evaluation on the occurrence of recorded fish species. However, information on the specific location in the river where individual species were found is severely limited. The species most mentioned are less common or rare, such as sturgeon, bitterling, grayling, ziege and asp (Ozoliņ̌s, 1929; Bērziņš, 1936; Ozols, 1937; Bērziņš, 1938). The finding of a new freshwater fish species, barbel Barbus barbus, was noted by Krēmanis (1937).

More recent lists of freshwater fish found in Latvia, published in the 1940s and 1950s (Priedìtis, 1947; Николаев, 1953; Sloka, 1956), overall are similar with previous reports. New fish species added to the list were barbel (Sloka, 1956) and Alpine sculpin Cottus poecilopus. It is surprising that one author (Priedìtis, 1947) considered coastal waters to be the habitat of Aphine sculpin, when later it was reported (Sloka, 1956) for both coastal and inland waters.

Little research on river fish occurrence was conducted prior to 1960 , but popular literature for anglers contains lists of fish species and gives specific rivers in which they can be caught. Angler's publications contain information about the distribution of game and coarse fishes in rivers and river basins (Priedītis, 1951).

In 1956, the first report on fish species occurrence in a specific Latvian river (Venta) was published (Шапошникова, 1958). The Venta River was reported to contain 17 species of fish at that time, but in addition, 14 fish species and two species of lamprey were added from information obtained from local persons. In total, 25 species of fish were recorded in studies on ichthyoplankton in the Lower Daugava and its reservoirs (Редлих, 1963; Гаумига, 1967; 1971; Костричкина, 1975). An article on the ichthyofauna of the Salaca River basin lists 23 species of fish (Звиргздс, 1987).

At this time, it was scientifically verified that Latvian rivers contain blue bream. This species was found in the Pḷavinas Reservoir on the Daugava River (Дирипаско, 1988).

The publication "Fishes" ("Zivis") lists all fish species whose range includes Latvia's inland bodies of water or coastal waters, species that are rare immigrants, species for which introduction was attempted, as well as species that could feasibly be found in Latvia, since they are found in neighbouring countries (Plikšs un Aleksejevs, 1998).

There are several inconsistencies in the publications. Grayling was likely mistakenly included in the list of fish found in the Daugava (Сапунов, 1893); other authors did not report this fish as occurring in the Daugava (Ozols, 1937; Sloka 1966; 1974). Some species that were mentioned as common in commercial catches in then Daugava (Сапунов, 1893) were considered by other authors as "rare" such as sturgeon, or as "occasional strayers", such as sea lamprey (Kawall, 1858; Берг, 1911).

The allis shad was mentioned for the first time as occurring in Latvia in 1925, but this species was omitted in a publication but the same author a few years later (Schneider, 1925; 1928). Other authors had mixed views on the occurrence of this species. Siliņš (1936) claimed that it was more common than twaite shad, while others did not mention this species (Сапунов, 1893), or stated its occurrence as a possibility (Николаев, 1953). Later, Sloka (1956), in reference to (Берг, 1948), wrote that this species did not occur in the Baltic Sea at all. A verified catch of this species in Latvia is unknown.

The above-mentioned examples illustrate that, in some cases, the basis for inclusion of a species to the list of fauna was taken either from an unverified source, or from speculation in a review of the ichthyofauna at a larger regional level. Scientific publications in Latvia mention species whose range borders are close to Latvia.

Krēmanis (1937) stated that he found a barbel in the Riga marketplace, caught in the Liepāja Harbor situated in the River Bārta mouth. Soon afterward, referencing Krēmanis, Mannsfeld (1939) wrote that this fish species was caught in the Lower Bārta River. Consequently, barbel has been included in lists of Latvia's freshwater fish since 1956, and specifically for the Bārta River (Sloka, 1956). An individual of the species was caught in coastal waters of the area in 2006. However, such individual occurrences are not reason enough to include the species in the list of fish occurring in Latvia's rivers. Barbel is native species in Lithuania (river Nemunas basin) and Belarus (rivers belonging to the Black Sea basin). Presumably, the barbel specimens caught in Lat- 
via coastal waters migrated northward from the Kuronian Lagoon.

Bullhead (sculpin) is mentioned as occurring in the Daugava (Сапунов, 1893). It is included as a rare species found in fresh- and coastal waters (Mansfelds, 1936; Sloka, 1956), yet it is not even mentioned in other lists of fish occurring in Latvia (Siliņš, 1936). In later publications (Николаев, 1953; Sloka 1966; 1974) it is mentioned as commonly occurring, which is in accordance with knowledge today.

Another species of the Cottidae family, Alpine sculpin, is mentioned as possibly occurring in Latvia (Mansfelds, 1936; Берг, 1949). Later, it was included in lists of the ichthyofauna of Latvia (Priedītis, 1947; Sloka, 1956; 1966; 1974). However, no verifiable specimen of this species has been caught in Latvia. This species is also not found in Latvia's neighbouring countries: Estonia (Ojaveer et al., 2003), Belorussia (Жуков, 1988), or Lithuania (Virbickas, 2000).

Since 1949, studies published in the former Soviet Union consider that the Daugava bullhead is subspecies Cottus gobio koshewnikowi of Russian bullhead (Берг, 1949; Жуков, 1965). The main morphological difference between the Russian bullhead and the common bullhead is an incomplete lateral line (Берг, 1949; Жуков, 1965). However, it is noted that this difference is not visible on all individuals (Берг, 1949). The incomplete lateral line may be visible only on young bullhead individuals, but differences are not visible in adult bullhead (Смирнов, 1986).

Blue bream has been included in lists of Latvia's fish in different periods of time. Some authors consider this fish to be a river species (Сапунов, 1893), while others to-live in coastal waters and lower river courses (Siliňš, 1936; Mansfelds, 1936; Николаев, 1953; Sloka, 1956; Priedītis, 1960). However, a verifiable specimen that would prove the species occurrence in Latvia has been recorded only once (Дирипаско, 1988). This fish species occurs in the Russian region of Pskov specific lakes that are connected to the Daugava River (Лесненко, 1988). It is possible that some blue bream individuals from these lakes can enter the Daugava and its reservoirs. However, not any capture of blue bream has been recorded in rivers of Latvia since 1988.

Many authors have not been consistent in regard to inclusion of fish species on the Latvian list of fish. For example, in the 1950s, the sterlet Acipenser ruthenus, which was introduced into the Daugava in 1885 (Сапунов, 1893) and later released in larger numbers in 1948 (Andrušaitis, 1960), was added to the list. The Prussian carp Carassius gibelio was also introduced in 1948 (Andrušaitis, 1960), and was consequently listed as occurring in our waters (Sloka, 1956). Fish species introduced in Latvia, but which were not previously listed as found in Latvia (Mansfelds, 1936), such as Arctic charr Salvelinus alpinus, brook charr Salvelinus fontinalis and rainbow trout Oncorhynchus mykiss, were included on Latvia's fish species lists for a period of time (Sloka, 1956), but later they were omitted
(Sloka, 1966; 1974). Allis shad has also disappeared from the lists. Since the 1950s, two more species have been introduced, Baikal omul Coregonus migratorius and inconnu Stenodus nelma (Andrušaitis, 1960), but they are never been included in the lists of the fauna of Latvia.

\section{FISH ACCLIMATIZATION AND INTRODUCTION}

The first fish introduction mentioned in publications on fish and fisheries in the rivers was the release of sterlet in the Daugava (Сапунов, 1893). Fish introduction and acclimatization in rivers was conducted on a wider level during the 1960s-1980s (Каиров и Костричкина, 1970; Римш, 1977, Aleksejevs, 2011). During this period, 11 fish species were introduced into Latvian waters: Siberian sturgeon Acipenser baerii, Russian sturgeon Acipenser gueldenstaedtii, sterlet, beluga Huso huso, muksun Coregonus muksun, broad whitefish Coregonus nasus, peled Coregonus peled, pink salmon Oncorhynchus gorbuscha, chum salmon Oncorhynchus keta, coho salmon Oncorhynchus kisutch and rainbow trout, and in the 1980s - the Amur sleeper Percottus glenii, which was done without authorization (Aleksejevs, 2011).

A few fish species are restocked and introduced in natural water bodies in and outside of their natural distribution range due to different reasons, but mainly to achieve larger populations of fish species with higher market value or for commercial fishing and angling. Pikeperch can be viewed as a largely artificially distributed fish species. Its natural distribution territory in Latvia included coastal waters and the lower courses of the largest rivers and their associated lakes - seven lakes and 5-6 of the largest rivers. Now it is found throughout Latvia. Until 1980, its introduction was largely ineffective. However, currently it has been observed to be forming self-sustaining populations after the introduction of fry and one summer-old fish, as well as by dispersal through rivers that connect lakes. The expansion of pikeperch through inland waters of Latvia probably has been promoted by climate change (Aleksejevs un Birzaks, 2009).

The grayling was introduced into at least nine rivers in the Daugava and Lielupe river basins, starting from 1999-2010. It was not observed in these river basins before that time (Ozols, 1961). Also, the catfish was artificially introduced outside of the Daugava River basin (Aleksejevs, 2010).

Glass eel has been restocked in at least 81 lakes of Latvia (Plikšs un Aleksejevs, 1998). At present, eel occurs also in the rivers upstream of hydroelectric power stations (HPS) dams.

Most of the fish species introduced into Latvia's natural bodies of water are no longer found. Only two invasive species have formed self-sustaining populations in rivers Prussian carp and Amur sleeper. Carp, which were introduced to Latvia already in the middle Ages, has reproduced poorly in Latvia's natural bodies of water. Today, carp, 
rainbow trout and charr fry are found mostly in rivers that are in close proximity to fish farms.

\section{CHANGES OF FISH OCCURRENCE AND DISTRIBU- TION IN RIVERS}

The occurrence and distribution of fish have changed significantly during the last 80-100 years due to human impact. In some cases, a decrease of distribution area has occurred (for example, decreasing of number of rivers accessible for diadromous fish species). In other cases, the occurrence and distribution has increased by introduction of an alien species, or by restocking and introduction of domestic species as compensation measures or occasional release of fish (Богуцкая и Насека, 2004).

The greatest changes have been observed in diadromous fish populations. Between 1939 and 1974, three HPS were constructed on Latvia's largest river, the Daugava. As a result, the number of rivers available to diadromous fish species, such as salmon, trout, vimba, river lamprey and eel, has drastically declined (Евтюхова, 1971; Песлак и Митанс, 1991). The largest part of the Daugava river basin (24 $700 \mathrm{~km}^{2}$ in Latvia) and about 40 of its tributaries have become inaccessible to the diadromous fish species. According to the literature (Жуков, 1965; 1988), up until the Daugava was dammed, these fish species reached into the territories of Belorussia and Russia, a distance of more than $500 \mathrm{~km}$ from the Gulf of Riga. It should be noted that the vimba has partly adapted to the situation, forming a population in the Plavinas Reservoir within the middle course of the river.

After the river Daugava was blocked by the HPS cascade, commercial fisheries data in the Gulf of Riga and rivers demonstrate a decreasing anadromous fish share in yearly catches, from $3300 \mathrm{t}$ in 1960-1977 to $1600 \mathrm{t}$ in 1978-1985 (Ojaveer and Gaumiga, 1995). This tendency has continues up to the present, and the catches of anadromous fish species in the last 25 years period have averaged only about $700 \mathrm{t}$ (Table 1).

Probably, loss of habitat is not the only reason why the occurrence and distribution of migratory fishes in Latvia's rivers have decreased. Other reasons may be the expansion of cod in the Riga Gulf ecosystem, periodical changes in the

Table 1

CATCHES (T) OF ANADROMOUS SPECIES IN THE GULF OF RIGA AND RIVERS (1960-2010)

\begin{tabular}{lccc}
\hline \multicolumn{1}{c}{ Species } & Years 1960-1977 & Years 1978-1985 & Years 1985-2010 \\
\hline Salmon & 112.0 & 47.9 & 55.3 \\
Sea trout & 8.7 & 0.5 & 5.7 \\
River lamprey & 241.3 & 31.8 & 110.1 \\
Vimba & 50.8 & 32.7 & 73.3 \\
Smelt & 1547.4 & 601.5 & 239.8 \\
Stickleback & 1271.7 & 873.6 & 250.7 \\
Eel & 27.8 & 2.6 & 1.5 \\
\multicolumn{1}{c}{ Total } & 3259.7 & 1590.6 & 736.4
\end{tabular}

Riga Gulf hydrology regime, pollution and eutrofication of rivers (Ojaveer and Gaumiga, 1995; Ряполова, 1972), change of a rivers' hydrology regime and poor spawning conditions (Ojaveer and Gaumiga, 1995). Since 1990, the number of rivers with species such as salmon, river lamprey vimba, white fish and eel has decreased (Table 2).

However, occurrence of some fish species has changed due to other natural and complex impacts. Archaeological research on settlements from the $8^{\text {th }}-1^{\text {st }}$ millenary BC has shown that some fish species, such as pikeperch, catfish and asp (Sloka, 1970; 1977; 1988), were more common in rivers than in the $19^{\text {th }}$ century and during the first half of the $20^{\text {th }}$ century.

Publications from the 1920s indicate that, in the first half of the $20^{\text {th }}$ century, the bitterling was found only in southwestern Latvia, up to the Daugava River (Schneider, 1925). According to current observations, it spread to the Salaca River (Звиргздс, 1987), and was later observed in Northern Latvia (22 $\left.27^{\prime} 41^{\prime} / 58^{\circ} 53^{\prime} 22^{\prime \prime}\right)$ and Eastern Latvia (26³9'22"/5703'03”) (Aleksejevs un Birzaks, 2008). This fish species has not been observed in Estonia (Ojaveer et al., 2003).

Carp has been introduced in Latvia since the $13^{\text {th }}$ century (Andrušaitis, 1960). Since the second half of $20^{\text {th }}$ century, two invasive fish species Prussian carp and Amur sleeper have spread in the inland waters (Aleksejevs, 2011).

\section{RECENT RESEARCH RESULTS}

Since 1990, surveys of fish distribution and relative abundance have been conducted throughout Latvia. All fish species and specimens, not only target species for anglers and commercial fisheries, have been routinely caught and analyzed. In total, 38 fish species and two lamprey species have been confirmed since 1990 in Latvia's rivers, using electrofishing, gillnets and seine as capture methods.

In the 20 years period since 1990, 43 fish species and three lamprey species have been caught and recorded in Latvia's rivers. Some of them, such as sea lamprey, twaite shad, whitefish, smelt and ziege, have been found only in commercial catches. Studies on the Gauja River have confirmed 30 species (43 fish and lamprey species) that can be potentially found (Birzaks, 2007).

Since 2008, a new species was observed in Latvia's rivers, first thought to be golden loach Sabanejewia aurata. The closest known locations of this species are in Poland in the Odra River basin (first detected in 1994), and in Lithuania in the Venta River basin (first detected in 2002) (Steponenas, 2003). The species was first detected in Latvia in the Gauja River, and a year later in the Daugava River basin (Birzaks, 2009; Aleksejevs, Birzaks, 2010).

According to the numbers of rivers that a species are found in, the most common fish are stone loach, found in 205 rivers ( $65.5 \%$ of rivers), and perch, pike and roach, found in 
FISH SPECIES OCCURRENCE AND RELATIVE ABUNDANCE IN THE RIVERS OF LATVIA

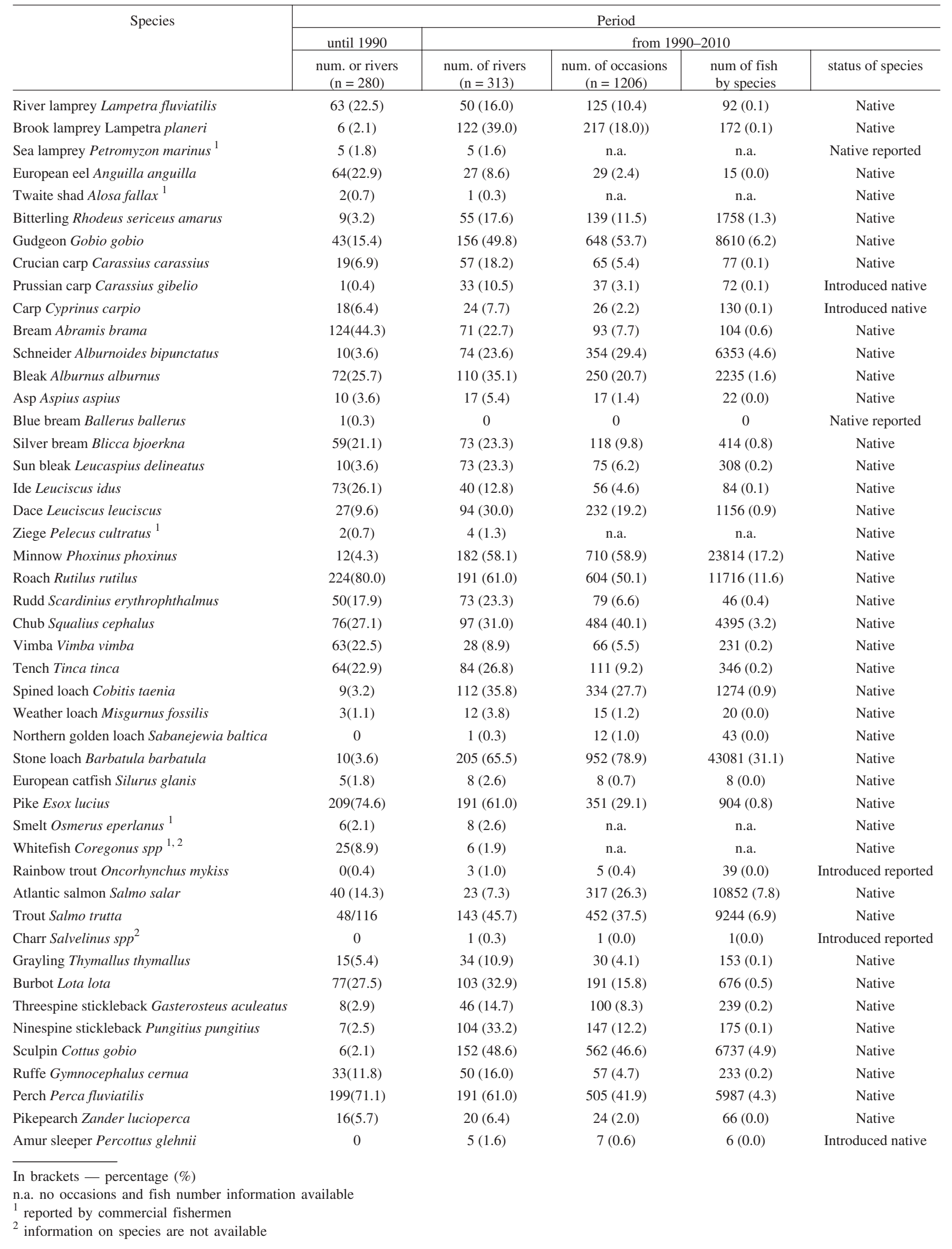


191 rivers $(61.0 \%)$. Other common species are minnow, found in 182 rivers $(58.1 \%)$, gudgeon, found in 156 rivers $(49.8 \%)$, and bullhead, found in 152 rivers $(48.6 \%)$. The invasive species Prussian carp, carp and Amur sleeper are found in $35(10.5 \%), 24(7.7 \%)$, and $5(1.6 \%)$ rivers, respectively. In total, 36 fish and lamprey species are found in more than $5 \%$ of the rivers.

The most common fish species found in different fishing areas are stone loach, minnow and gudgeon. They have been caught, respectively, in the following number of capture events: $952(78.9 \%$ of the total number of fishing occasions), $710(58.8 \%)$, and $648(53.7 \%)$. Other common species are roach - $64(50.1 \%)$, bullhead - $562(46.6 \%)$, perch $-505(41.9 \%)$, and trout - $452(37.5 \%)$. According to the number of specimens caught during surveying of rivers, $60 \%$ of them are composed of three species: stone loach $-31.3 \%$, minnow $-17.2 \%$, and roach $-11.6 \%$. The salmonids, salmon and trout, were caught in $7.8 \%$ and $6.9 \%$ of capture events (Table 2).

The authors have created a list of fish species occurring in Latvia's rivers, which includes only those species that have been caught and verified after 1990. Some of these species are rare strayers (sea lamprey, twaite shad, ziege and whitefish), which require greater fishing effort to provide specimens than is possible during routine surveys. Their capture has been reported and the caught individuals were confirmed by experts.

Some species migrate into rivers during autumn (river lamprey) and winter-early spring seasons (river lamprey, smelt), when fish sampling is not carried. Their adults and fry stay in the rivers for only a short period (e.g. smelt). However, these species are exploited by commercial fishery.

In total, the number of species used in aquaculture is growing, as is the number of aquaculture enterprises and their production capacity. According to available data, there are currently 12-15 different species of fish from various systematic groups found in hatcheries; some of them are caught in Latvia's rivers, although rarely.

In our interpretation, the local fish species that are found in their natural range and breed in Latvia's rivers (included the catadromous species eel) are native species (Table 2). Species that are found in their range, but whose breeding has not been not proven in our rivers, are native reported (NR) species. Introduced species that breed in Latvia's conditions are introduced native (IN) species, but those that do not breed are introduced reported (IR) species.

In summary, it can be concluded that previous fish species lists that have been previously published have many errors. The main cause of this has been insufficient field study, and in some cases, acceptance of unverified data as fact. This pertains mainly to species that are not target species of angling and/or commercial fishing. The geographical range of some species has shrunk, while for others the geographical range has been artificially increased. Recent surveys show that the occurrence of fish in rivers much differs from that previously reported. The above-mentioned changes in fish occurrence and distribution can be verified only if the specific locations, number of locations and relative numbers of fish per species are known.

\section{CHANGES IN FISH NOMENCLATURE}

Nomenclature of European fishes has undergone significant changes. The rules of the International Code of Zoological Nomenclature prescribe a system of naming, i.e., each species has a name consisting of generic name and specific name. This means that formerly described subspecies are no longer recognised. This concept is followed by the largest web resource on fish nomenclature

www.calacademy.org/research/ihthyology (Богуцкая и Насека, 2004).

At present, 546 native fish species are recognized for $\mathrm{Eu}-$ rope, 47 of them have been recently discovered by researchers who follow the Phylogenetic Species Concept. Most likely, the list of fish species for Latvia needs to be revised. In some cases, identification of species belonging to the Coregonidae, Cottidae and Cobitidae can be difficult, especially in field conditions (Kottelat and Freyhof, 2007).

Fundamental differences exist in the views on systematics of Cottidae, Maitland (2000) believes that only three bullhead species are found in Europe, while others (Kottelat and Freyhof, 2007) distinguish eight species. The mapped distributions of these species in the publications indicate that Alpine sculpin and bullheads do not occur in Latvia. The distributiuon range of the Volga bullhead is drawn from the Daugava to the North (Kottelat and Freyhof, 2007). Presently, there are at least 100 locations containing bullhead south of the Daugava. This species occurs in 152 rivers throughout Latvia (Table 2) and is found in all of Latvia's neighbouring countries (Жуков, 1988; Virbickas, 2000; Ojaveer et al., 2003).

The systematic status of the Russian bullhead (Volga sculpin) is obviously controversial, as some authors call it a species (Kottelat and Freyhof, 2007), some a subspecies (Берг, 1949; Жуков, 1965; 1988), and others a haplotype (Maitland, 2000). Recently it was proposed to identify the Russian bullhead as a separate species Cottus koshewnikowi, naming it the Volga sculpin (Kottelat and Freyhof, 2007).

As with the bullhead, a revision in the systematics of Cobitidae is also needed. It has been hypothesized that the golden loach in the Baltic Sea basin is a new species northern golden loach Sabanejewia baltica (Kottelat and Freyhof, 2007).

Views on the occurrence of sturgeon in the Baltic Sea basin are also currently changing. Archeological excavations have shown that in the distant past $\left(1,000\right.$ B.C.E. $-13^{\text {th }}$ and $14^{\text {th }}$ centuries), sturgeon was a relatively common fish (Sloka, 
1970; 1977). All publications on Latvia's ichthyofauna have mentioned sturgeon, specifically Atlantic sturgeon, as occurring in Latvia's rivers. Atlantic sturgeon disappeared from the Baltic Sea basin around 800 years ago; in the last few years it has been proposed that the Atlantic Sturgeon were replaced by American Atlantic sturgeon Acipenser oxyrinchus (Kottelat and Freyhof, 2007), which is now found only in North America. In this case, it can be concluded that both species were once found in Latvia's rivers. The last few known individuals caught were considered to be American Atlantic sturgeon.

Introduction of various fish from the sturgeon family in Latvia and other countries on the Baltic Sea has been conducted since at least 1885 . The specimens caught in Latvia have been neither morphologically analyzed, nor have they been subjected by genetic testing. News of sturgeon-type fish, probably beluga, caught in the Gulf of Riga was published as early as in the $19^{\text {th }}$ century (Sodoffsky, 1857). In 1960-1970 bycatch of specimens from the sturgeon family fish were common, their numbers and rate of occurrence in catches of commercial fisheries was highest in years following their restocking (Каиров, Костричкина, 1970). The latest recorded specimen, probably American Atlantic sturgeon, was caught in 1996 in the Gulf of Riga (Ojaveer et al., 2003).

We consider that whitefish systematics is particularly complicated. The scientific name of whitefish Coregonus lavaretus applies only to the species from lake Borguet (France). This denomination was adopted and has been used for all species of whitefishes in the whole area of its distribution, also in the basin of the Baltic Sea (Kottelat and Freyhof, 2007). Regarding the whitefish occurring in the Baltic Sea basin, it has bee proposed to name the migratory form spawning in the rivers as Coregonus maraena, and the sea spawning forms as Coregonus widegren. Peipsi whitefish Coregonus maraenoides and Ludoga whitefish Coregonus lutokk (Kottelat and Freyhof, 2007) are considered to be new species, which have been introduced into some of Latvia's rivers. Similarly, in the 1930s, whitefish were divided into three forms, identifiable by the morphology of gillrakers (Mannsfeld, 1930). The whitefishes caught in Latvia since the 1930s have not been analyzed morphologically, nor genetically, and therefore, it is impossible to say which species they belong to.

It is likely that the proposed species Ludoga whitefish and Peipsi whitefish can successfully breed fertile offspring. Ludoga whitefish and Peipsi whitefish were introduced into Sevana Lake in Armenia. After 40 years, a self-sustaining population had evolved. Most of its individuals exhibited a morphology characteristic of both species (Шапошникова, 1971).

\section{CONCLUSIONS}

In total, 43 fish and three lamprey species have been caught in the rivers of Latvia after 1990, 41 of these species have established self-sustainable populations, three of them are invasive. One new native fish species was found in Latvia during this period. Sturgeon has disappeared, and the single and last record of blue bream was recorded in 1988.

Previous publications on the fauna of Latvia incorrectly list some species (allis shad, Alpine sculpin and barbell) as occurring in rivers of Latvia. No verified records exist on the existence of a self-sustaining population of blue bream existence in Latvia in the $20^{\text {th }}$ century, and both sturgeon species are extinct.

Two invasive species, Amur sleeper and Prussian carp, form self-sustaining populations in rivers. Carp reproduction in natural waters is ineffective, and the occurrence and distribution of this species are dependent on restocking of carp in natural waters or carp escape from aquaculture.

The changes in native fish species occurrence and distribution have been caused by natural and anthropogenic factors. The distribution of salmon, vimba and river lamprey has decreased due to habitat loss. Such species, such as pikeperch, catfish and grayling, have been restocked, and occur outside of their natural area of distribution.

Changes in fish nomenclature raise a need for a revision of Latvia's fish fauna list in the immediate future.

Our review demonstrates that updates of fish occurrence and distribution data are necessary to indicate changes in fish fauna over time. Quantitative data on fish occurrence and distribution are needed for further development of the typology of Latvia's rivers.

\section{REFERENCES}

Aleksejevs, Ē., Birzaks, J. (2008). Spidil,ka Rhodeus amarus Bloch izplatiba Latvijā [Distribution of bitterling Rhodeus amarus Bloch in Latvia] (5.-6. lpp.). LU 66. zinātniskā konference. Klimata mainība un ūden,i. Rakstu krājums. Rīga (in Latvian).

Aleksejevs, E., Birzaks, J. (2010). Zivis - potenciālie klimata izmaiņu indikatori [Fishes as potential climate chages indicators] (6.-14. 1pp.). $L U$ 68. zinātniskā conference. Klimata mainība un üden,i. Rakstu krājums. Rìga (in Latvian).

Aleksejevs, Ē. (2011). Zivju introdukcija un aklimatizācija Latvijā [Introduction and acclimatization of fishes in Latvia] (61.-68. lpp.). Grām.: Latvijas zivsaimniecības gadagrāmata 2010. Rīga (in Latvian).

Aleksejevs, Ē., Birzaks, J. (2009). Izmaiṇas zandarta Sander lucioperca (L.) izplatībā Latvijas iekšējos ūdenos [Changes in the distribution of pikepearch Sander lucioperca (L.) in Latvia's inland waters] (10.-15. lpp.). LU 67. zinātniskā konference. Klimata main̄̄ba un ūden,i. Rakstu krājums. Rīga (in Latvian).

Andrušaitis, G. (1960). Zivju savairošana un aklimatizācija Latvijā [Breeding and acclimatization of fishes in Latvia] (41.-70. lpp.). Grām.: Latvijas PSR iekšèjo ūdeņu zivsaimniecība IV. Rīga (in Latvian).

Anonīms (1984). Latvijas padomju enciklopēdija [Latvian Soviet Encyclopedia]. 5. sēj. 2. grām. 1. izdevums. Rīga. 800 lpp. (in Latvian).

Anonīms (2009). Upju baseinu apgabalu apsaimniekošanas plāni [River basin districts management plans].

www.vidm.gov.lv/lat/darbibas_veidi/udens_aizsardziba_/upju_baseini/

Bērziņš, B. (1936). Salates Lielupē [Asp in the River Lielupe] (156. lpp.). Grām.: Daba un zinātne. Nr. 5. Rīga (in Latvian). 
Bērziňš, B. (1938). Rhodeus sericeus Pallas Lielupē [Rhodeus sericeus Pallas in the River Lielupe] (29. lpp.). Grām.: Daba un zinātne. Nr. 1. Rìga (in Latvian).

Birzaks, J. (2007). Zivis. [Fishes] (189.-193. lpp.). Grām.: Biologiskā daudzveidība Gaujas Nacionālajā parkā. Sigulda (in Latvian).

Birzaks, J. (2009). Jauna zivju suga Sabanejewia aurata (De Filippi, 1865) Latvijā [The new fish species Sabanejewia aurata (De Filippi, 1865) in Latvia] (Rīga. 39.-40. 1pp.). Klimata mainība un ūdeņi LU 67. Zinātniskā konference. Rakstu krājums (in Latvian).

Dybowski, B. (1862). Versuch einer Monographie der Cyprinoiden Livlands nebst einer synoptischen Aufzählung der europäischen Arten dieser Familie. Archiv für die Naturkunde Liv-, Ehst- und Kurlands, zweiter Serie, Bd. III. Dorpat. 133-362 S.

Eglīte, R. (1961). Upes nēǵa Lampetra fluviatilis (L.) migrācijas un nārsts Latvijas PSR upēs [Migration and reproduction of river lamprey Lampetra fluviatilis (L.) in the rivers of the Latvian SSR] (9.-28. 1pp.). P. Stučkas Latvijas Valsts Universitātes Zinātniskie raksti. 39. sēj. Biol. zinātnes. Rīga (in Latvian).

Eglīte, R. (1975). Upes nēǵa Lampetra fluviatilis (L.) nozvejas pieaugums Latvijas PSR upēs [Increase of river lamprey Lampetra fluviatilis (L.) catches in the rivers of Latvia SSR] (99.-104. 1pp.). Zoologijas muzeja raksti, 12. Vertebrata. Rīga (in Latvian).

Eipurs, I. (1984). Mūsu saldūden,u zivis. [Our freshwater fishes]. Rīga. 103 lpp. (in Latvian).

Fischer, J. (1791). Versuch einer Naturgeschichte von Livland. Konigsberg. $826 \mathrm{~S}$.

Gaumiga, R., Berzinsh, V., Urtans, E. (1997). Impact of environmental factors on the fish community of the Gulf of Riga (pp. 205-210). In: Proceedings of 13th Baltic Marine Biologists Symposium. Riga.

Grosse, A. (1935). Pisces. Zivis [Fishes] (196.-218. 1pp.). Grām.: Latvijas mugurkaulaiṇu noteicējs. Rīga (in Latvian).

Kawall, H. (1858). Fische in Kurland und an den Küsten der dasselbe begränzenden Ostsee, mit Berücksichtigung von Livland. Das Inland. 23. Jahrg. Dorpat. Nr. 33, 534-536 S., Nr. 35, 561-598 S., Nr. 36, 579-583 S.

Kottelat, M., Freyhof, J. (2007). Handbook of European Freshwater Fishes. Berlin. 646 pp.

Krēmanis, A. (1937) Jauna zivs mūsu ūdeņos [New fish species in our waters]. Zvejniecības mēnešraksts, Nr. 9, 278-279 (in Latvian).

Maitland, P.S. (2000). Guide to Freshwater Fish of Britain and Europe. London: Hamlyn. 256 pp.

Mannsfeld, W. (1930). Studien an Coregonen des Ostbaltikums. Archiv Fur Hydrobiologie, 20(1), 65-94.

Mannsfeld, W. (1939). Mitteilungen zur Fischfauna Lettlands III. Korrespondenzblatt des Naturforscher-Vereins zu Riga, 63, 43-47.

Mansfelds, V. (1936). Latvijas zivis [Fishes of Latvia] (490.-519. 1pp.). Grām.: Latvijas zeme, daba un tauta. II. Rīga (in Latvian).

Ojaveer, E., Gaumiga, R. (1995). Cyclostomes, fishes and fisheries (pp. 212-267). In: Ecosystem of the Gulf of Riga between 1920 and 1990. Tallin.

Ojaveer, E., Pihu, E., Saat, T. (eds.) (2003). Fishes of Estonia. Tallinn. 416 pp.

Ozoliņ̌s, V. (1929). Mūsu retākās zivis [Our rare fish species] (149.-150. 1pp.). Zvejniecības mēneřraksts, Nr. 10 (in Latvian).

Ozols, E. (1937). Par alatas (Thymallus thymallus (L.)) izplatību [On grayling (Thymallus thymallus L.)) distribution]. Daba un zinātne, Nr. 5, 189 (in Latvian).

Ozols, G. (1961). Alatas un to makšķerēšana [Grayling and their angling]. Mednieks un makšķernieks, Nr. 3, 13-14 (in Latvian).

Pastors, A. (1988). Cik esam bagāti [As rich we are] (73.-78. 1pp.). Dabas un vēstures kalendārs 1989. gadam. Rīga (in Latvian).

Plikšs, M., Aleksejevs, Ē. (1998). Zivis [Fishes]. Rīga. 304. lpp. (in Latvian).
Plotnieks U., Priedītis A. (1980). Zivis un makškerēšana [Fishes and Angling]. Rīga. 157. 1pp. (in Latvian).

Priedītis, A. (1947). Zivkopība [Fish farming]. Rīga. 422. lpp. (in Latvian).

Priedīitis, A. (1951). Zivju migrācijas un nozveja Padomju Latvijas ezeros un upēs [Catches and fish migrations in the lakes and rivers of Soviet Latvia]. Rīga. 72. lpp. (in Latvian).

Priedītis, A. (1960). Ar makškseri Latvijas PSR ezeros un upēs [With an angling tackle in lakes and rivers of the Latvian SSR]. Rìga. 147 lpp. (in Latvian).

Schneider, G. (1925). Die Süsswasserfische des Ostbaltikums und ihre Verbreitung innerhalb des Gebietes. Archiv für Hydrobiologie, 16, 133-155.

Schneider, G. (1928). Die Seefischerei von Lettland und Estland. In: Handbuch der Seefischerei Nordeuropas. Band VIII, Die Seefischerei der scandinavischen und osteuropaischer Lander, Heft 6. Stuttgart. 34 S.

Siliņš, J. (1936). Latvijas zivis [Fishes of Latvia]. Jaunais zinātnieks, Nr. 37, 87 (in Latvian).

Sloka, J. (1956). Cyclostomata - Apalmutes [Jawless fishes Cyclostomata] (7.-8. lpp.). Grām.: Latvijas PSR dzīvnieku noteicējs. 2. daḷa. Mugurkaulnieki. Rīga (in Latvian).

Sloka, J. (1956). Pisces - Zivis [Pisces - Fishes] (9.-61. lpp.). Grām.: Latvijas PSR dzīvnieku noteicējs. 2. dalı. Mugurkaulnieki. Rīga (in Latvian).

Sloka, J. (1966). Apaḷutes - Cyclostomata [Jawless fishes - Cyclostomata] (94.-95. lpp.). Grām.: Latvijas dzīvnieki. Rīga (in Latvian).

Sloka, J. (1966). Zivis - Pisces [Fishes - Pisces] (74.-93. lpp.). Grām.: Latvijas dzìvnieki. Rīga (in Latvian).

Sloka, J. (1970). Bronzas laikmeta zivis senajā Daugavā [Bronze age fishes in the River Daugava]/ Latvijas PSR Zinātṇu Akadēmijas Vēstis, Nr. 11, 33-39 (in Latvian).

Sloka, J. (1974). Apalmutes - Cyclostomata [Jawless fishes - Cyclostomata] (100.-101. lpp.). Grām.: Latvijas dzīvnieku pasaule. Rīga (in Latvian).

Sloka, J. (1974). Zivis - Pisces [Fishes - Pisces] (87.-99. 1pp.). Grām.: Latvijas dzīvnieku pasaule. Rīga (in Latvian).

Sloka, J. (1977). Rīgas XII-XIV gs. kultūras slānī atrastās zivis [Fishes in $12^{\text {th }}-14^{\text {th }}$ century Riga] (100.-107. 1pp.). Latvijas PSR Zinātnuu Akadèmijas Vèstis, Nr. 6 (in Latvian).

Sloka, J. (1988). Akmens laikmeta lomi [Stone age catches] (47., 53. lpp.). Grām.: Dabas un vēstures kalendārs 1989. gadam. Rīga (in Latvian).

Sodoffsky, W. (1849). Ueber die Störgattungen des caspischen und schwarzen Meeres. Korrespondenzblatt des Naturforschenden Vereins zu Riga. Dritter Jahrgang. No. 5, 69-81.

Steponenas, A. (2003). Golden loach (Sabanejewia aurata (De Filippi, 1865)) - a new freshwater fish species in Lithuania. Acta Zoologica Lituanica, 13(3), 279-282.

Šternbergs, M. (1988). Gliemeṇu auklētās zivis [The mussels nursed fishes] (35. lpp.). Grām.: Dabas un vēstures kalendārs 1989. gadam. Rīga (in Latvian).

Virbickas, J. (2000). Lietuvos Žuvys [Fishes of Lithuania]. Vilnius, 192 pp. (in Lithuanian).

Берг Л.С. (1911). Фауна России и сопредельныхъ странъ. Рыбы. (Marsipobranchii u Pisces ) [The fauna of Russia and neighbouring countries. Fishes]. T. 1. С.-Петербургъ. 337 с. (in Russian).

Берг Л.С. (1948). Рыбы пресных вод СССР и сопредельных стран [Freshwater fishes of the USSR and neighbouring countries]. Часть. 1. Москва - Ленинград, 466. с. (in Russian).

Берг Л.С. (1949). Рыбы пресных вод СССР и сопредельных стран [Freshwater fishes of the USSR and neighbouring countries]. Часть. 3. Москва - Ленинград, с. 929-1382 (in Russian).

Богуцкая Н.Г., Насека А.М. (2004). Каталог бесчелюстных и рыб пресных и солоноватых вод России с номенклатурными и таксономическими комментариями [Catalogue of freshwatwer and brackhish- 
water lampreys and fishes of Russia with commentaries on nomenclature and taxonomy]. Москва. 389 c. (in Russian).

Дирипаско О.А. (1988). О поимке синца Abramis ballerus в Плявиньском водохранилище (бассейн Даугавы) [Capture of blue bream Abramis ballerus in the reservoir Plaviтas (the River Daugava)]. Bonpoсы ихтиологии, 28(4), 688-689 (in Russian).

Гаумига Р.Я. (1967). О роли Даугавы в пополнение запасов весенненерестующих рыб [The importance of River Daugava on fish resources reproduction] (c. 197-204). В кн.: Рыбохозяйственные исследования 8 бассейне Балтийского моря. Сборник 3, Рига, (in Russian).

Гаумига Р. Я. (1971). К вопросу о рыбохозяйственном использовании Плявиньского водохранилища [On the fishery exploitation of the Plavinas reservoir] (с. 55-70). В кн.: Рыбохозяйственные исследования в бассейне Балтийского моря. Сборник 8, Рига (in Russian).

Жуков П.И. (1965). Рыбы Белоруссии [Fishes of Belorussia]. Минск. 415 c. (in Russian).

Жуков П.И. (1988). Справочник по экологии пресноводных рыб [Наndbook of Freshwater Fish Ecology]. Минск. 310 c. (in Russian).

Звиргздс А. (1987). Ихтиофауна рек бассейна Салаца [The fish fauna of the River Salaca basin] (c. 148-153). В кн.: Биоценотическая структура мальх рек (Бассейн реки Салаца). Рига (in Russian).

Евтюхова Б.К. (1971). Балтийский лосось [Baltic salmon]. Рига. 48 с. (in Russian)

Каиров Е.А., Костричкина Е.М. (1970). Результаты интродукции осетровых в бассейн Балтийского моря [Results of sturgeon introduction in the Baltic Sea basin] (c. 147-152). Тр. ВНИРО. том LXXVI. Москва (in Russian).

Костричкина Е.M. (1975). Питание и пищевые отношения рыб Кегумского и Плявиньского водохранилищ [The feeding and food chains of fishes in reservoirs of Ķegums and Pḷavinas] (c. 66-76). Рыбохозяйственные исследования в бассейне Балтийского моря. Сборник 11. Рига (in Russian).

Лесненко В.К. (1988). Псковские озера [The lakes of Pskov]. Ленинград. 112 c. (in Russian).

Митанс А.П. (1971). Сравнительная характеристика условий существования, питания и роста молоди лосося в реках Латвии [Comparison of growth, feeding and living conditons of salmon parr in the rivers of Latvia] (c. 3-54). Рыбохозяйственные исследования в бассейне Балтийского моря. Сборник 8. Рига (in Russian).

Митанс А.П. (1975). Эффективность естественного и искуственного воспроизводства балтийского лосося как результат особенностей его пресноводного периода жизни [Efficiency of wild and artificial reproduction of Baltic salmon as a result of their freshwater life factors] (c. 110-152). Рыбохозяйственные исследования в бассейне Балтийского моря. Сборник 11. Рига (in Russian).

Николаев И.И. (1953). Видовой состав рыб Латвийской ССР [The species composition of fishes of Latvia SSR] (c. 5-27). Труды Латвийского отделения ВНИРО. Вып. 1. Рига (in Russian).

Песлак Я.К., Митанс А П. (1991). Состояние естественного и заводского воспроизводства сырти в бассейне Рижского залива [The state natural reproduction and artificial restocking of vimba in the Gulf of Riga basin] (c. 75-83). В кн.: Аквакультура на Балтике. Рига (in Russian).

Редлих А.К. (1963) Характеристика ихтиофауны Кегумского водохранилища [Characteristics of Hegums reservoir fish fauna] (c. 249-256). Гидробиология и ихтиология внутренних водоемов Прибалтики. Рига (in Russian).

Римш Е.Я. (1977). Опытные работы по акклиматизации тихоокеанских лососей в Балтийское море [The research projects of introduction of $\mathrm{Pa}$ cific salmon in the Baltic sea] (c. 100-107). Рыбохозяйственные исследования в бассейне Балтийского моря. Сборник 13. Рига (in Russian).

Ряполова Н. И. (1972). Речная минога восточной Балтики [River lamprey of East Baltic]. Рига. 44 c. (in Russian).

Ряполова Н. И. (1968). Возможности прогнозирования динамики запасов и уловов латвийской миноги [The possibilities of Latvian river lamprey stock and catch prediction] (c. 199-214). Рыбохозяйственные исследования в бассейне Балтийскогоморя. Сборник 4. Рига (in Russian).

Сапунов А. (1893). Река Западная Двина [The river Daugava]. Витебск. 512. c. (in Russian).

Смирнов А.И. (1986). Фауна Украины [The fauna of the Ukraine]. Том 8. Рыбы. Выпуск 5. Окунеобразные (бычковидные), скорпенообразные, камбалообразные, присоскоперообразные, удильщикообразные. Киев, c. 320. (in Russian)

Спирина Л.И. (1968). Состояние запасов сырти Рижского залива в условиях современного регулируемого промысла [The state and management of the Gulf of Riga vimba stock] (c. 183-198). Рыбохозяйственные исследования в бассейне Балтийского моря Сборник 4. Рига (in Russian).

Шапошникова Г.Х. (1958). Материалы по ихтиофауне реки Вента [Маterials on the River Venta fish fauna] (c. 313-322). Рыбное хозяйство внутренних водоемов Латвийской ССР, II, Труды VII, Рига (in Russian).

Шапошникова Г.Х. (1971). Сравнительно-морфологическое описание сигов рода Coregonus оз. Севан [The comparative morfological description of whitefishes family Coregonus in the lake Sevan] (c. 575-586). Вопросы ихтиологии, 11(4) (in Russian).

\section{ZIVJU SASTOPAMĪBA UN IZPLATĪBA LATVIJAS UPĒS}

Apkopoti dati par 435 Latvijas upēs un uz tām izveidotajās ūdenskrātuvēs sastopamajām zivju un nēǵu sugām. Konstatētas 43 zivju un trīs nēğu sugas, kuru dzīves cikls kaut daḷēji ar tām saistīts. Tās iedalās saldūdens sugās un ceḷotājzivju sugās. Analizētas atškirīības hronoloğiski vecākajās publikācijās par zivju sastopamību salīdzinājumā ar mūsdienās iegūtiem datiem laikā pēc 1990. gada un šo atšķirību rašanās cēloṇi. Laikā pēc 1990. gada pētījumu intensitāte Latvijas upēs ir pieaugusi, kas faktiski arī nosaka izmaiṇas priekšstatos par zivju sastopamību un relatīvo daudzumu. Autori piedāvā savu Latvijas upēs sastopamo zivju sugu saraksta versiju, kas pamatota ar iepriekšējo pētîjumu analīzi un kvantitatīviem zivju uzskaites datiem pēc 1990. gada. Tajā iekḷautas sugas, kas Latvijas upēs konstatētas pētỉjumos vai kuru noḳeršanas gadījumi bijuši verificēti. 